\title{
BODY COMPOSITION AND DEGREE OF WEIGHT MATURITY IN RABBITS OF SEVERAL GENOTYPES
}

\author{
J. OUHAYOUN et R. ROUVIER \\ avec la collaboration technique de Danièle Decmas et C. JAcourn \\ Laboratoive de Méthodologie génétique, \\ Centre de Recherches de Toulouse, I. N.R. A., \\ 31320 Castanet Tolosan
}

Variation in the chemical composition of rabbit carcasses of six genotypes was studied during growth. The six genotypes were the result of mating sires of three lines : Géant Blanc du Bouscat, New-Zealand, Petit Russe with dams of the two latter lines. The adult weight of the three sire lines were different, Petit Russe being the ligh test $(2.5 \mathrm{~kg})$. Three rabbits per genotype were studied at six stages of growth: I4, 28, 42,70,84 and 182 days.

Between I 4 and 182 days, the two components of overall growth : multiplication of nucleoli as estimated by the level of DNA and protein synthesis $(\mathrm{N} \times 6.25)$ did not vary with the same relative rate for the six genotypes. The proteinogenesis, relative to the rate of DNA synthesis, was more intense when the adult size was small.

A relation between the water content of the carcass $(y)$ and the degree of maturity in terms of live weight $(p)$ at 84 days of age is presented :

$$
\log y=-0.294 \log p+4.933 \quad(r=-0.987)
$$

The correlation between water and lipid contents of the carcass was quite high $(r=-0.993)$ between genotypes and between the logarithmic values).

With respect to young animals, the carcasses of more mature animals showed relatively higher dry matter and lipid contents.

\section{VARIATION IN THE NUMERICAL PRODUCTIVITY AT WEANING AND IN ITS COMPONENTS BETWEEN GENOTYPES OF CHOSSBRED AND PUREBRED RABBITS}

\author{
B. POUJARDIEU et J. L. VRILLON \\ Labovatoire de Méthodologie génétique, \\ Centre de Recherches de Toulouse, I. N.R.A., \\ 31320 Castanet Tolosan
}

